\title{
An Analysis of the Educational Testing Service Major Field Test for Business Performance: Further Evidence
}

\author{
Zahid Iqbal, PhD \\ Texas Southern University, Houston, Texas, United States \\ Contact: zahid.iqbal@tsu.edu
}

\begin{abstract}
Assurance of learning is the key to students' academic success. To this end, one of the largest historically Black colleges and universities (HBCUs) in the United States administers the Educational Testing Service Major Field Test for Business (ETS MFT-B) to assess student learning of business concepts. This study used a set of predictor variables to explain the ETS MFT-B performance at the subject HBCU. The results of the study are expected to close the gap between student performance and expected outcomes in the subject institution, as well as contribute to the broader issue of improving curriculum and teaching effectiveness in business schools in the United States. Using data from fall 2012 to fall 2018, the findings of the regressions indicated that new variables, namely, English language proficiency, hours attempted to hours earned, first-generation student status, and desire to pursue higher studies were important predictors of the ETS MFT-B total score and subscores. Among the traditional variables, the cumulative GPA and student's major area were important predictors. These findings point toward several corrective actions in the assurance-of-learning process for the subject school. The subject school can add a business English class to the curriculum, improve teaching effectiveness, provide advising assistance when students retake classes, and adopt measures that will motivate students to prepare for the ETS MFT-B.
\end{abstract}

Keywords: Assurance of learning; curriculum improvement; ETS MFT-B performance; $H B C U$

Date Submitted: December 14, 2019 | Date Published: August 10, 2020

\section{Recommended Citation}

Iqbal, Z. (2020). An analysis of the Educational Testing Service Major Field Test for Business performance: Further evidence. Journal of Educational Research and Practice, 10, 242-253.

https://doi.org/10.5590/JERAP.2020.10.1.16

\section{Introduction}

An important task of collegiate business schools is to establish an assurance-of-learning process for their degree programs. They must define learning goals for each degree and align the curricula with the goals. The school of business at a large historically Black college and university (HBCU) has selected "understanding of business concepts" as one of the learning goals for its bachelor of business administration (BBA) degree. The school assesses its learning goal using the Educational Testing Service's Major Field Test in Business (ETS MFT-B). As the scores of the test were below expectations for several years, the school implemented several arbitrary measures to improve performance with no positive results. 
To contribute to the assurance-of-learning process, this study examined whether the ETS MFT-B scores for the school of business at the subject HBCU can be explained by certain traditional predictors used in prior studies and by a set of new predictors. The results of this study will guide the subject school in making curriculum improvements on business concepts and addressing broader issues such as student learning, teaching effectiveness, and student advising.

The paper provides a review of the literature, descriptions of the data, sample, and methodology, empirical results, and concluding remarks.

\section{Literature Review}

The ETS MFT-B, introduced in 1990, is an external measure of assessment widely used for undergraduate business programs. Specifically, the test consists of 120 multiple-choice questions measuring basic knowledge of business for seniors. The test is scaled with scores ranging from 120 to 200, and the questions are selected from nine business and business-related areas with each area sub-score ranging from o to $100 \%$. According to Mirchandani et al. (2001), the test can be easily administered, is relatively inexpensive, and the results can be compared with those of peer institutions. Two major concerns are that performance on the test is best predicted by performance on other standardized exams and that it may not reflect actual knowledge of business concepts.

A number of early research studies examined the predictors of the ETS MFT-B scores. Ritchie et al. (2014, Table 1) provided a list of the significant predictors. Among the demographic variables, gender was an important variable with male students outperforming female students (Bagamery et al., 2005; Black \& Duhon, 2003; Chowdhury \& Wheeling, 2013; Contreras et al., 2011; Mason et al., 2011; Mirchandani et al., 2001). Bielinska-Kwapisz and Brown (2013) showed that male students outperform female students on the ETSMFT-B, but the advantage disappears when a critical thinking variable is introduced. Hence, the gender difference can be attributed to critical thinking ability. Contreras et al. (2011) and Mason et al. (2011) found that older students performed better on the ETS MFT-B than younger students. Black and Duhon (2003) posited that age is a proxy for work experience; hence, older students perform better because they have longer work experience.

Among the variables often categorized as ability variables, key predictors of the ETS MFT-B score are high school grade point average (HS-GPA) (Allen \& Bycio, 1997) and scores on standardized tests, e.g., SAT or ACT (Allen \& Bycio, 1997; Black \& Duhon, 2003; Bycio \& Allen, 2007; Chowdhury \& Wheeling, 2013; Contreras et al., 2011; Mason et al., 2011; Mirchandani et al., 2001). High school GPA measures initial academic ability, while ACT or SAT scores measure ability to take a standardized test and a student's overall intellectual aptitude.

Almost all the studies listed in Table 1 in Ritchie et al. (2014) found that cumulative GPA, either overall, business, general education, or transfer, is an important predictor of ETS MFT-B performance. The ETS MFTB test score is supposed to be correlated with how students perform at various stages of the curriculum. Hence, class grades are positively associated with the ETS MFT-B score. It can be argued that cumulative GPA depends on other factors such as type of test administered, teaching effectiveness of the instructors, and textbook used. Mason et al. (2011) argued that if GPAs and SAT or ACT scores predict understanding of business concepts, then ETS MFT-B assessment adds little value and is a waste of the university's resources.

A number of studies found that a student's major area explained the ETS MFT-B score (Allen \& Bycio, 1997; Black \& Duhon, 2003; Mason et al., 2011). Allen and Bycio (1997) and Mason et al. (2011) found that accounting and finance majors scored higher than other majors on the ETS MFT-B. Also, Ritchie et al. (2015) observed that finance students had better ETS MFT-B scores than other majors. Contreras et al. (2011) 
explained that the ETS MFT-B performance can be better in some major areas because of the way course materials in the major areas were designed and test-taking skills were developed.

Allen and Bycio (1997) used extra credit awarded in the strategy class as a motivation variable for students who took the ETS MFT-B. A later study by Bycio and Allen (2007) showed that student motivation measured by survey data was a significant predictor of ETS test score. Another study by Terry et al. (2008) used multiple levels of grades awarded in the capstone class as the motivation variable. They pointed out that the use of a tangible motivator in a capstone class may have limited effects because for students in the final semester, one capstone course grade may not have a huge impact on their overall GPA.

Ritchie et al. (2015) found evidence that student prerequisite classes such as English and mathematics explained the ETS MFT-B score. A properly designed set of prerequisite classes helped students understand the business concepts better. Simmons et al. (2015) added an extra-curricular variable, namely, membership in the School of Business Mentor Association, as a proxy for high achievers. Their findings showed that the cumulative GPA, HS-GPA, SAT score, as well as the membership variable had significant and positive relationships with the ETS MFT-B score. Settlage and Wollscheid (2015) added a new variable, namely, number of courses completed in key functional areas, to the list of explanatory variables. They found that course counts in areas such as marketing, management, and finance had positive associations with the ETS MFT-B score. Their results for the other variables such as gender, age, GPA, and ACT scores were consistent with those observed in prior studies.

This study utilized some of the variables used in prior studies and a set of new variables. One new variable, whether a student's first language is English, is expected to capture competency in English language primarily for $23.3 \%$ of foreign students in the initial sample. Although foreign students are required to take the Test of English as a Foreign Language (TOEFL) or International English Language Testing System (IELTS) test, many continue to struggle with the course materials. Terry et al. (2008) pointed out that international students often face unique language, psychic, and cultural challenges that might negate some of their innate ability and work ethic. We expect that students whose first language is English will exhibit high scores on the ETS MFT-B.

The data for the initial sample in this study showed that an average business student at the subject institution attempted 155 hours and earned 131 hours during the sample period (not reported). Thus, a student attempted 35 additional hours or about 11 additional classes than the 120 hours needed for a BBA degree. Overall, with only a $21 \%$ graduation rate, students at the subject institution took more classes than required to earn their degree. To capture the relationship with additional hours taken by the students, we used a new variable defined as attempted hours to earned hours. This variable can measure a student's ability to successfully pass a class in the first attempt, and hence the level of academic achievement. It can also indicate that a student improves learning by being persistent and by taking a class multiple times to successfully complete the degree requirements. We expect the relationship between the ratio of hours attempted to hours earned and the ETS MFT-B to be either positive or negative.

About 30.6\% of the students in the initial sample were first generation. Prior research showed that firstgeneration students, whose parents did not have a college degree, possessed a lower level of cultural capital and were less likely to succeed in college than the continuing-generation students. They were less confident in their academic ability and less likely to have a high GPA. An empirical study by Mehta et al. (2011) found that first-generation students had a low GPA when compared to continuing-generation students. Following this line of argument, we expect the ETS MFT-B score for first-generation students to be below that of continuinggeneration students.

The school of business in the subject institution does not provide any tangible motivation to perform well on the ETS MFT-B. Students are encouraged to perform well but there are no incentives attached to the subject 
school's exit exam. Since direct motivators are not available, we utilized data from the exit exam survey on their future plan to pursue higher education as a proxy for student motivation. We argue that those who plan to pursue higher studies have a higher level of motivation and prepare better for the ETS MFT-B. We expect that this group of students will score high on the ETS MFT-B when compared to those who do not wish to pursue higher studies. A significant and positive relationship between the higher studies variable and the ETS MFT-B score will encourage the subject school to implement motivators for students to prepare and complete the test successfully.

\section{Data, Sample, and Methodology}

This study used data from the school of business at the subject HBCU in the United States. Data collected were for 2,548 BBA students who took the ETS MFT-B from fall 2005 to fall 2018. Key data included ETS MFT-B total score and sub-scores, survey data on English as a second language, and desire to pursue higher studies. Additional data were obtained from the subject university's graduation and application databases. These data from fall 2012 to fall 2018 available for 1,657 students included cumulative GPA, hours attempted, hours earned, major area of study, age, gender, and first-generation student status. Data on HS-GPA, ACT and SAT scores, and first-time transfer status were collected from the application and graduation databases from spring 2011, which is the first year these data were available, to fall 2018.

We cross matched the cases by student identification numbers listed on the ETS MFT-B and graduation and application databases. The initial sample size after cross matching resulted in 1,001 BBA students. Table 1 provides the list of the initial variables. The outcome variables in Table 1 are the ETS MFT-B total score and sub-scores for the five BBA major areas in the school of business.

The ability variables measured a student's ability to perform well on the ETS MFT-B. They included HS-GPA, transfer GPA, cumulative GPA for all undergraduate courses, score on standardized SAT-Math, and proficiency in English language. Generally speaking, a student with good HS and transfer GPAs is likely to develop better understanding of business concepts in a college than a student with poor HS and transfer GPAs. Since HS-GPA data were available for only 230 students, we added the transfer GPA to increase the sample size to 595 students. The HS/transfer GPA measures academic performance outside of a student's home institution. Similarly, a business student who graduated with a high cumulative GPA is likely to have mastered key concepts in business. The SAT scores measured students' skill on taking a standardized test and their natural ability to perform in a business program. Although the subject university added standardized test scores and HS-GPA to admissions criteria from fall 2008, these data were not readily available. Data for SAT composite were available for only two students, SAT-Math for 135 students, ACT composite for 90 students, and ACT-Math for 90 students. We did not use the composite scores because of the unusually large number of missing data. Instead we converted the ACT-Math scores and replaced them with the missing SATMath scores. The conversion provided us with 197 cases of SAT-Math scores.

The next set of variables were termed process variables that enhance a student's knowledge and understanding of business concepts. The process variables used were (a) the student's transfer status, (b) cumulative hours attempted and earned, and (c) the student's major area. Terry et al. (2008) argued that classes at a junior community college have less rigor and do not adequately prepare students for business programs. Hence, a transfer student is expected to score low on the ETS MFT-B. As explained in an earlier section, hours attempted to hours earned may capture a student's natural ability to understand business concepts; or it may suggest that repeating classes strengthens understanding of class materials. A student's major area can also affect the ETS MFT-B score (Allen \& Bycio, 1997; Black \& Duhon, 2003: Mason et al., 2011). Following Contreras et al. (2011), students perform better on the ETS MFT-B because of the way they developed test taking skills in a specific major area. 
Demographic variables included the student's age at the time of graduation and gender. First-generation student and higher studies are coded variables which were expected to have a positive relationship with the ETS MFT-B scores.

$$
\begin{aligned}
\text { Score }_{i}= & \beta+\beta_{\mathrm{j}} \text { Ability }_{\mathrm{j}, \mathrm{i}}+\beta_{\mathrm{j}} \text { Process }_{\mathrm{j}, \mathrm{i}}+\beta_{\mathrm{j}} \text { Demographic }_{\mathrm{j}, \mathrm{i}}+\beta_{\mathrm{j}} \text { First Generation }_{\mathrm{j}, \mathrm{i}}+ \\
& \beta_{\mathrm{j}} \text { Higher Studies }_{\mathrm{j}, \mathrm{i}}+\varepsilon_{i}
\end{aligned}
$$

where,

Score $_{i}=$ ETS MFT-B total score or sub-score for student $\mathrm{i}$,

Ability $\mathrm{j}, \mathrm{i}=$ Ability variable $\mathrm{j}$ for student $\mathrm{i}$,

Process $\mathrm{j}, \mathrm{i}=$ Process variable $\mathrm{j}$ for student $\mathrm{i}$,

Demographic $\mathrm{j}_{\mathrm{j}, \mathrm{i}}=$ Demographic variable $\mathrm{j}$ for student $\mathrm{i}$,

First Generation $_{\mathrm{j}, \mathrm{i}}=$ First-generation student variable $\mathrm{j}$ for student $\mathrm{i}$,

Higher Studies $\mathrm{j}_{\mathrm{j}, \mathrm{i}}=$ Higher studies variable $\mathrm{j}$ for student $\mathrm{i}$, and

$\beta=$ Regression parameter for variable $j$.

\section{Findings}

\section{Descriptive Statistics}

Table 1 provides descriptive statistics for the initial variables. Examining the relationships between these variables and the ETS MFT-B score will guide the subject school in taking corrective actions for student learning of business concepts. The data in Table 1 showed a mean ETS MFT-B score of 135.8, which was below the mean values reported in prior studies. For example, Settlage et al. (2015) reported a mean score of 151.3 and Bycio and Allen (2007) reported a mean score of 161.9. This score was also below that of the Association to Advance Collegiate Schools of Business (AACSB) peer institutions and selected HBCUs and significantly below that of the national average of 151.6 (Source: ETS Comparative Report, Spring 2019). Thus, understanding of overall business concepts by the students in the subject school of business is not at par with that of the business schools examined in prior studies and in peer institutions. A careful review of the ETS MFT-B data showed that 42 or $4.19 \%$ of the 1,001 sample students had the lowest possible score of 120 (not reported in Table 1). These students are more likely to be the ones with no motivation to perform on an ETS test. In subsequent regression analysis, we dropped cases with an ETS MFT-B score equal to 120. These findings showed that the mean sub-scores for the BBA degree areas in the subject school of business ranged from $31.98 \%$ in accounting to $43.06 \%$ in management.

Under the ability category, HS/transfer GPA data were available for 595 or $59.4 \%$ of the students, SAT-Math (with ACT conversion) data for 197 or $19.7 \%$ of the students, and English language proficiency data for 811 or 81.0\% of the students. The findings showed that the mean HS/transfer GPA was 2.89, while the mean cumulative GPA was 2.97, indicating that course grades from the BBA programs were about the same as the course grades from high school and transfer institutions. The low mean SAT-Math score of 440 indicated that the incoming students were not capable of learning college-level materials especially in the quantitative areas. On English language proficiency, 811 or $81.0 \%$ of the students provided information on their first language. The chi-square value (not reported) showed that there was a strong positive association between English 
language proficiency and international student status. Of the 167 international students that completed the survey question, 63 or $37.7 \%$ indicated that English was their second language. Of the 644 citizens or permanent residents that completed the survey question, a significantly higher number, 605 or $93.9 \%$, indicated that English was their first language.

Under the process variables, the findings showed that $38.3 \%$ were first-time transfer students. The mean value of cumulative hours attempted was 154.64 hours, while the mean value of cumulative hours attempted to earned ratio was 1.18 , indicating that students attempted about $18 \%$ more classes than passed. Of the five major BBA programs, management information systems (MIS) had the lowest percentage (6.7\%), while management had the highest percentage (30.4\%) of the undergraduate students in the sample.

For the demographic variables, the mean age of students who graduated from the subject business school during the sample period was 26.94 years. About $53.9 \%$ of the graduates were male, $30.6 \%$ were firstgeneration students, and 60.9\% expressed interest in pursuing higher studies. 
Iqbal, 2020

Table 1. Descriptive Statistics

\begin{tabular}{|c|c|c|c|c|c|c|}
\hline \multirow{2}{*}{ Variables } & & \multirow[b]{2}{*}{$\%$} & \multicolumn{4}{|c|}{ Score or Value } \\
\hline & & & Mean & Min & $\operatorname{Max}$ & SD \\
\hline \multicolumn{7}{|l|}{ Outcome } \\
\hline ETS Total Score & 1001 & & 135.80 & 120.0 & 190.0 & 10.61 \\
\hline Accounting Score & 1001 & & 31.98 & 0.0 & 82.0 & 12.33 \\
\hline Finance Score & 1001 & & 33.15 & 0.0 & 86.0 & 13.21 \\
\hline Management Score & 1001 & & 43.06 & 0.0 & 89.0 & 15.88 \\
\hline MIS Score & 1001 & & 41.72 & 0.0 & 83.0 & 16.40 \\
\hline Marketing Score & 1001 & & 38.55 & 0.0 & 93.0 & 15.78 \\
\hline \multicolumn{7}{|l|}{ Ability } \\
\hline High School or Transfer GPA & 595 & & 2.89 & 0.66 & 4.0 & 0.67 \\
\hline Cumulative GPA & 1001 & & 2.97 & 2.1 & $3 \cdot 9$ & 0.37 \\
\hline SAT-Math Score & 197 & & 440 & 230 & 675 & 79.21 \\
\hline $\begin{array}{l}\text { English Language Proficiency } \\
\text { (o-1) }\end{array}$ & 811 & $82.4 \%$ & 0.82 & 0.0 & 1.0 & 0.38 \\
\hline \multicolumn{7}{|l|}{ Process } \\
\hline First-Time Transfer (o-1) & 1001 & $38.3 \%$ & 0.38 & 0.0 & 1.0 & 0.49 \\
\hline Cumulative Hours Attempted & 1001 & & 154.64 & 120.0 & 303.0 & 29.91 \\
\hline $\begin{array}{l}\text { Cumulative Hours } \\
\text { Attempted/Earned }\end{array}$ & 1001 & & 1.18 & 1.0 & 2.3 & 0.19 \\
\hline Accounting Major (o-1) & 1001 & $24.8 \%$ & 0.25 & 0.0 & 1.0 & 0.43 \\
\hline Finance Major (o-1) & 1001 & $24.0 \%$ & 0.24 & 0.0 & 1.0 & 0.43 \\
\hline Management Major (o-1) & 1001 & $30.4 \%$ & 0.30 & 0.0 & 1.0 & 0.46 \\
\hline MIS Major (o-1) & 1001 & $6.7 \%$ & 0.07 & 0.0 & 1.0 & 0.25 \\
\hline Marketing Major (o-1) & 1001 & $14.2 \%$ & 0.14 & 0.0 & 1.0 & 0.35 \\
\hline \multicolumn{7}{|l|}{ Demographic } \\
\hline Age & 1001 & & 26.94 & 20.0 & 73.0 & 6.79 \\
\hline Gender (o-1) & 1001 & $53.9 \%$ & 0.54 & 0.0 & 1.0 & 0.50 \\
\hline First-Generation Student (o-1) & 1001 & $30.6 \%$ & 0.47 & 0.0 & 1.0 & 0.50 \\
\hline Higher Studies (0-1) & 785 & $60.9 \%$ & 0.61 & 0.0 & 1.0 & 0.49 \\
\hline
\end{tabular}

\section{Regression Results}

Table 2 presents the regression results on the ETS MFT-B total score and sub-scores. The results showed how the explanatory variables were related to ETS score, which will guide the subject school in improving the assurance-of learning-process. The results of this study will have implications for the assurance of student learning in business schools in the United States. The HS/transfer GPA and SAT-Math score variables were not included in the regression to keep the sample size large. Including these two variables would have dropped the sample size drastically to 141 cases. Additionally, we omitted 42 cases with an ETS MFT-B score of 120 because these students may have submitted blank tests. 
Iqbal, 2020

\section{Total Score}

The first column, labelled Total Score, reports the findings on the ETS MFT-B total score. The $\mathrm{R}^{2}$ value for the regression was $11.2 \%$ indicating that the explanatory variables explained only $11.2 \%$ of the variations in ETS MFT-B in the subject school of business. This value was below that observed in prior studies (e.g., 45.6\% in Bagamery et al., 2005, and 39.0\% in Ritchie et al., 2014). The findings in Table 2 showed that the coefficient for the English language proficiency was positive and significant, indicating that a student whose first language is English scored 4.72 points higher than a student whose first language is not English. This new finding indicated that a student whose native language is English understands and interprets ETS MFT-B questions better than a student whose first language is not English. Requiring a business English class in lieu of a general elective for a student whose native language is not English can improve understanding of business concepts as well as English competency, and, hence, the performance on the ETS test.

The coefficient for the cumulative GPA was also positive and significant suggesting that a student who received better grades in college courses performed better on the ETS MFT-B. This finding on cumulative GPA is consistent with those in prior empirical studies such as Allen and Bycio (1997), Bagamery et al. (2005), and Mason et al. (2013). The results showed that a student with a one point higher cumulative GPA scored 8.03 more points on the ETS MFT-B. Overall, students enrolled in the business programs with better abilities measured by English proficiency and higher cumulative GPA demonstrated a better understanding of basic business concepts at the time of graduation. Improving curriculum contents and delivery methods are likely to improve a student's academic performance and, ultimately, the score on the ETS MFT-B.

In the process variables category, unlike the findings in prior studies, the data did not show any association between the ETS MFT-B score and the transfer variable. The argument in Terry et al. (2008) that the class quality at a junior community college was inadequate did not hold for students in the subject HBCU. Apparently, students who transferred from the local community colleges to the subject HBCU received quality instruction in general education. The second process variable, hours attempted to earned ratio, is a new variable whose coefficient value is significant at the conventional level. The result suggested that students in the subject school scored 5.20 higher on the ETS MFT-B if they attempted 1\% more classes than passed. Retaking failed classes suggested persistency of the business students and their ability to improve understanding of class materials. The academic advisors in the subject school can get involved by helping students retake the classes when performance is not satisfactory. We did not include the student major variable for the regression on total score because of lack of argument linking the ETS MFT-B score and all five major areas in the subject business school. The student major variable was used for regressions on the subscores.

Unlike the findings in prior studies, none of the two demographic variables were significant in explaining the ETS MFT-B scores for gender (Chowdhury \& Wheeling, 2013; Mirchandani et al., 2001) and for age (Contreras et al., 2011; Mason et al., 2011). It appears that such anomaly on the demographic variables did not hold for the HBCU students. The data in Table 2 showed that the coefficient for the first-generation students was positive and significant suggesting that this group of students scored 2.23 points higher on the ETS MFTB. This finding did not bode well with the argument that the first-generation students, who do not have a higher level of cultural capital, are less likely to perform academically. Apparently, the first-generation students at an HBCU have a higher level of commitment to excel and perform better on the ETS MFT-B. These students performed better because of the additional financial support they received at an HBCU. The coefficient value of 2.43 for the higher studies variable was positive and significant indicating that students who had an interest to pursue higher studies scored 2.43 higher on the ETS MFT-B. We argue that students who have a desire for higher studies have a higher level of commitment and motivation to review class materials and take the ETS test seriously. This finding, that motivated students perform better, indicated that the subject institution can add motivators such as class credit in the capstone class to improve ETS MFT-B performance. 


\section{Sub-Scores}

The total ETS MFT-B score measured understanding of overall concepts in nine business or related areas, namely, accounting, finance, management, marketing, MIS, economics, quantitative, business law, and international business. It was also important to know how students performed in each discipline or major area.

Table 2 reports the results of the sub-scores. The results showed that both English language proficiency and cumulative GPA were important predictors of knowledge in the discipline areas. The coefficients for these two ability variables were positive and significant. Similar to the findings for total score, business students with better English language proficiency and better grades scored high on the area ETS test. The findings showed that students scored the highest (8.12 points) in management if English is their first language. English language proficiency had a greater impact on non-quantitative areas such as management. The coefficient value for cumulative GPA was also highest for the management area. Students with a one-point higher GPA exhibited 10.12 additional ETS points on management topics.

In the process variables category, the first-time transfer variable was not significant for any of the major areas. The hours attempted to earned variable was significant for accounting, management, and marketing areas. For this variable, the coefficient of 7.05 for marketing had the highest value, indicating that students who attempted 1\% more classes scored 7.05 higher on ETS MFT-B in marketing. The findings on the third process variable, a student's major, showed significant and positive associations with all the sub-scores, with the MIS coefficient value showing the strongest association. The MIS students scored 6.90 points higher on the ETS MFT-B in MIS when compared to the ETS MFT-B in MIS score for other majors. Overall, improving curriculum and teaching effectiveness in each major area will enhance understanding of concepts in the major areas.

In demographics, the only significant variable was age in the accounting area. A younger student scored 0.12 higher in accounting when compared to other major areas. With regards to first-generation status, business students performed better in all major areas except for the finance area. These results for the school's business students were contrary to the findings in prior studies (Mehta et al., 2011). As explained in the previous section, the first-generation students showed a higher level of commitment than their counterparts in other institutions reported in prior studies. The higher level of financial support received by the first-generation students at the HBCUs can also contribute to greater performance. Finally, the higher studies variable had significant and positive associations with all five major areas. Of the five areas, students with plans to pursue higher studies scored the highest in management. These results suggested that motivators such as class credit can enhance student understanding of business concepts in all major areas. Providing additional reviews in all major areas in the capstone class can strengthen the assurance-of-learning process. 
Table 2. Regression Results

\begin{tabular}{lllllll}
\hline & $\begin{array}{l}\text { Total } \\
\text { Score }\end{array}$ & $\begin{array}{l}\text { Acct } \\
\text { Score }\end{array}$ & Fin score & $\begin{array}{l}\text { Mgmt. } \\
\text { score }\end{array}$ & $\begin{array}{l}\text { MIS } \\
\text { score }\end{array}$ & $\begin{array}{l}\text { Mktg. } \\
\text { score }\end{array}$ \\
\hline Constant & $101.74^{\mathrm{c}}$ & 0.40 & 8.79 & -1.39 & $17.74^{\mathrm{b}}$ & 7.06 \\
\hline Ability & & & & & & \\
\hline $\begin{array}{l}\text { English Language } \\
\text { Proficiency }\end{array}$ & $4.72^{\mathrm{c}}$ & $4.24^{\mathrm{c}}$ & $4.16^{\mathrm{c}}$ & $8.12^{\mathrm{c}}$ & $7.60^{\mathrm{c}}$ & 2.36 \\
Cumulative GPA & $8.03^{\mathrm{c}}$ & $7.24^{\mathrm{c}}$ & $5.57^{\mathrm{c}}$ & $10.12^{\mathrm{c}}$ & $5.92^{\mathrm{c}}$ & $7.50^{\mathrm{c}}$ \\
\hline Process & & & & & & \\
\hline First-Time Transfer & -0.63 & -0.30 & 1.33 & 1.65 & 0.93 & -1.96 \\
Hours & $5.20^{\mathrm{b}}$ & $4.95^{\mathrm{a}}$ & 0.72 & $5.97^{\mathrm{a}}$ & -3.54 & $7.05^{\mathrm{b}}$ \\
$\begin{array}{l}\text { Attempted/Earned } \\
\text { Student Major }\end{array}$ & $\mathrm{N} / \mathrm{A}$ & $4.22^{\mathrm{c}}$ & $3.64^{\mathrm{c}}$ & $3.80^{\mathrm{c}}$ & $6.90^{\mathrm{c}}$ & $4.46^{\mathrm{c}}$ \\
\hline Demographic & & & & & & \\
\hline $\begin{array}{l}\text { Age } \\
\text { Gender }\end{array}$ & -0.05 & $-0.12^{\mathrm{a}}$ & 0.03 & -0.06 & 0.13 & -0.08 \\
$\begin{array}{l}\text { First-Generation } \\
\text { Student }\end{array}$ & 0.66 & 0.44 & 1.34 & -0.34 & -1.44 & 0.42 \\
Higher Studies & $2.23^{\mathrm{c}}$ & $2.02^{\mathrm{b}}$ & 0.22 & $1.95^{\mathrm{a}}$ & $2.90^{\mathrm{b}}$ & $2.62^{\mathrm{b}}$ \\
$\begin{array}{l}\mathrm{R}^{2} \\
\text { F-statistic }\end{array}$ & $2.43^{\mathrm{c}}$ & $2.26^{\mathrm{c}}$ & $2.04^{\mathrm{b}}$ & $2.60^{\mathrm{b}}$ & 1.29 & $1.79^{\mathrm{a}}$ \\
\hline
\end{tabular}

aSignificant at the $10 \%$ level. bSignificant at the $5 \%$ level. cSignificant at the $1 \%$ level.

\section{Limitations and Future Research}

When considering the findings of this study, it is important to note several limitations. First, the study did not include SAT or ACT scores as a predictor because of unavailability of data and the sample size issue. Previous studies found that SAT or ACT scores had a positive and significant relationship with ETS MFT-B score. Second, the $\mathrm{R}^{2}$ value for the regressions were considerably low compared to the those observed in prior studies. Third, the higher studies variable was not a direct motivator for the ETS MFT-B. This variable was used as a proxy for aspiring students who were likely to take the test seriously.

While this study provided evidence that traditional predictors such as cumulative GPA and student's major area, as well as some of the new predictors, explained the ETS MFT-B performance at the subject HBCU, future research can be conducted using additional variables. New variables can include (a) percentage of online classes taken by the student, (b) the order in which the student took classes, (c) average size of student's classes, (d) percentage of classes taught by part-time instructors, and (e) percentage of student's two-day versus three-day classes. Futures studies can include comparisons of predictors between the subject institution and peer institutions. An examination of these additional variables will contribute towards the assurance-of-learning process, including curriculum improvements, class scheduling, faculty compositions, student advising, etc. 
Iqbal, 2020

\section{Conclusion}

This study examined the predictors of ETS MFT-B performance at an HBCU in the United States. The findings of the study shed light on the assurance-of learning process and corrective actions to improve performance on the ETS MFT-B. The regression analysis employed variables used in prior studies and a set of new predictors. The results showed that the English proficiency measure, cumulative GPA, cumulative hours attempted to hours earned, major area, first-generation student status, and desire to pursue higher studies were significant predictors of the ETS MFT-B total score as well as sub-scores. With regard to improving the low scores on ETS MFT-B, some of these predictor variables can be examined closely for planning purposes. For example, for students whose first language is not English, a business English class can be required in place of a general elective. International students will be better served by taking a business English class, which will improve their business vocabulary as well as English skill. Since students with a desire to pursue higher studies performed well on the ETS MFT-B, additional motivators such as class credit in a capstone class can be used to improve student performance. A significant and positive relationship between hours attempted to hours earned and ETS MFT-B suggested the extent of student persistence and student learning. Academic advising can help students get back on track to achieve student success. 


\section{References}

Allen, J., \& Bycio, P. (1997). An evaluation of the Educational Testing Service Major Field Achievement Test in Business. Journal of Accounting Education, 15, 503-514. https://doi.org/10.1016/So7485751(97)00021-3

Bagamery, B. D., Lasik, J. J., \& Nixon, D. R. (2005). Determinants of success on the ETS Business Major Field Exam for students in an undergraduate multisite regional university business program. Journal of Education for Business, 81, 55-63. https://doi.org/10.3200/JOEB.81.1.55-64

Bielinska-Kwapisz, A., \& Brown, F. W. (2013). Differential gender performance on the Major Field TestBusiness. Journal of Education for Business, 88, 159-166. https://doi.org/10.1080/08832323.2012.666296

Black, H. T., \& Duhon, D. L. (2003). Evaluating and improving student achievement in business programs: The effective use of standardized assessment tests. Journal of Education for Business, 79, 90-98. https://doi.org/10.1080/08832320309599095

Bycio, P., \& Allen, J. S. (2007). Factors associated with performance on the Educational Testing Service (ETS) Major Field Achievement Test in Business (MFAT-B). Journal of Education for Business, 82, 196201. https://doi.org/10.3200/JOEB.82.4.196-201

Chowdhury, M. I., \& Wheeling, B. (2003). Determinants of Major Field Test (MFT) score for graduating seniors of a business school in a small mid-western university. Academy of Educational Leadership Journal, 17, 59-71.

Contreras, S., Badua, F., Chen, J. S., \& Adrian, M. (2011). Documenting and explaining Major Field Test results among undergraduate students. Journal of Education for Business, 86, 64-70. https://doi.org/10.1080/08832323.2010.480987

Mason, P. M., Coleman, B. J., Steagall, J. W., \& Gallo, A. A. (2011). The use of the ETS Major Field Test for assurance of business content learning: Assurance of waste? Journal of Education for Business, 86, 71-77. https://doi.org/10.1080/08832323.2010.480988

Mehta, S. S., Newbold, J. J., \& O’Rourke, M. A. (2011). Why do first generation students fail? College Student Journal, 45, 20-35.

Mirchandani, D., Lynch, R., \& Hamilton, D. (2001). Using the ETS Major Field Test in Business: Implications for assessment. Journal of Education for Business, 77, 51-56. https://doi.org/10.1080/08832320109599671

Ritchie, C. M., Rodriguez, L. C., Harrison, D. S., \& Wates, K. W. (2014). The impact of prerequisite general education courses on the ETS Major Field Test for Business (MFT-B). Journal of Education for Business, 89, 292-299. https://doi.org/10.1080/08832323.2014.889065

Settlage, D. M., \& Wollscheid, J. R. (2015). Analyzing student performance in specific subject area indicators on the ETS Major Field Test in Business. Journal of Education for Business, 90, 322-327. https://doi.org/10.1080/08832323.2015.1058736

Simmons, S. A., Jones, W. M., Jr., \& Bolt, C. E. (2015). The Major Field Test in Business: A direct measure of learning in common business disciplines. Journal of Education for Business, 90, 57-62. https://doi.org/10.1080/08832323.2014.973825

Terry, N., Mills, L. V., \& Sollosy, M. (2008). Student grade motivation as a determinant of performance on the business major field ETS exam. Journal of College Teaching and Learning, 5, 20-25. https://doi.org/10.19030/tlc.v5i7.1244 
Iqbal, 2020

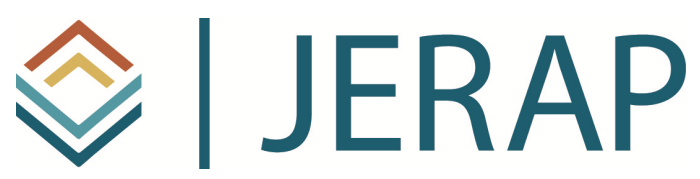

The Journal of Educational Research and Practice is a peerreviewed journal that provides a forum for studies and dialogue about developments and change in the field of education and learning. The journal includes research and related content that examine current relevant educational issues and processes. The aim is to provide readers with knowledge and with strategies to use that knowledge in educational or learning environments. JERAP focuses on education at all levels and in any setting, and includes peer-reviewed research reports, commentaries, book reviews, interviews of prominent individuals, and reports about educational practice. The journal is sponsored by the Richard W. Riley College of Education and Leadership at Walden University, and publication in JERAP is always free to authors and readers. 